PROBLEMS

OF EDUCATION

IN THE $21^{\text {st }}$ CENTURY

Vol. 77, No. 1, 2019

\section{ASSESSMENT OF SCIENCE TEACHERS' CAREER SATISFACTION AND SCHOOL ORGANISATIONAL CLIMATE IN ENHANCING JOB PERFORMANCE IN RURAL LEARNING ECOLOGIES}

Yinusa A. Faremi, Loyiso C. Jita

University of the Free State, South Africa

E-mail: akintoyeyinusa@gmail.com, jitaLC@ufs.ac.za

\begin{abstract}
Science teachers'career satisfaction and organisational climate, which influence their job performances, are very important. This research examined the extent to which science teachers'career satisfaction and organisational climate are related to their job performances in rural learning ecologies. Within a survey and correlational research design of a quantitative type, 250 science teachers were selected in Ondo State, Nigeria using a purposive sampling technique. Data were collected using an adapted questionnaire on science teachers' career satisfaction, school organisational climate and job performance. Descriptive and inferential statistics were used to analyse data. The results showed that $65.2 \%$ of the science teachers in rural learning ecologies were satisfied with their careers while $34.8 \%$ were dissatisfied with their careers. It was discovered that a combination of career satisfaction and organisational climate significantly influenced their job performances. It was found that the teachers' career satisfaction had a significant positive effect on their job performances while school organisational climate had a significant negative effect on their job performances. In light of the results, it can be concluded that science teachers' career satisfaction is the most effective significant contribution to their job performances. Further, it can be inferred that the school organisational climate does not significantly predict job performance in rural learning ecologies. To this end, results of the current research have some implications worth considering for the employers of science teachers, principals of schools and other stakeholders in creating a healthy school organisational climate and demonstrate good leadership behaviour in order to achieve improvement in the job performance of science teachers in rural learning ecologies.

Keywords: school organisational climate, science education, teachers'career satisfaction, teachers' job performance, rural learning ecologies.
\end{abstract}

\title{
Introduction
}

A career is an occupation undertaken for a particular period in someone's life and with opportunities for progress on the job. A career can also be referred to as a profession, occupation, vocation, calling or job. Science teachers play a key role in developing future leaders in science and technology by evoking the curiosity of students and encouraging further exploration into areas of interest. Teachers are the most important group of professionals in the nation's future, and without a teacher, the education system will suffer. In Nigeria and other parts of the world, the teacher finds it more difficult to cope with his or her financial obligations and societal expectations; hence, he or she becomes frustrated and therefore dissatisfied with his or her job. Satisfied teachers will be able to deliver quality education to students by motivating and inspiring them (Naz, 2017). 
Yinusa A. FAREMI, Loyiso C. JITA. Assessment of science teachers' career satisfaction and school organisational climate in enhancing job performance in rural learning ecologies

Castro and Martins (2010) explained that the organisational climate focused on organisational members, while job satisfaction addresses perceptions and attributes that people have towards demonstrating their potentials. The environment in which the science teachers perform their job and their emotional reactions to the job, especially their working conditions, wages and feeling of accomplishment are of utmost importance because it has a direct impact on the quality and quantity of job they do. Organisational climate refers to a set of attributes specific to a particular organisation it deals with members of the organisation and the work environment. Organisational climate draws the attention of the teachers and principals to discuss and interact with each other concerning the materials available in the school and the issues hindering the progress and achievement of the staff and the students (Attkinson \& Frechette, 2009 as cited in Selamat, Samsu, \& Kamalu, 2013).

The rural profile includes long distances to the towns, undesirable conditions of roads to schools, lack of or limited access to ICTs, lack of services such as electricity, health facilities, education and access to lifelong learning opportunities. Rural ecology may be regarded as an environment that fosters the creation of communities while a learning ecology is an environment that is consistent with how learners learn (Hlalele, 2011). For the purpose of this study, rural learning ecologies are schools that are not too close to the city and that fulfil some of the rural profiles highlighted above. The rural schools face difficulty recruiting and retaining new teachers, not just as a result of the highly qualified teachers' requirement, but of the teaching conditions unique to rural schools such as unfriendly school organisational climate, social and collegial isolations, low salaries and multiple subject teaching assignment (Monk, 2007 as cited in Barley, 2008). Together, these challenges can discourage teachers from accepting a rural teaching position or cause them to leave the rural settings after teaching for a short period of time in the school where they are positioned. Science teachers in this research were referred to as a set of teachers who teach a science-based subject such as Basic Science, Biology, Computer studies, Chemistry, Further Mathematics, Mathematics, Physics, Physical and Health Science Education.

The types of school where teachers were employed are also associated with teachers' decision to stay or leave. Literature reveals that in Arizona out of 9000 Arizona public school teachers over one-quarter were dissatisfied with their jobs. Almost $69 \%$ of these teachers had considered quitting their job at some points (Mertler, 2016). Research indicated that job performance was positively predicted by job satisfaction and the connection that exists between organisational tenure and job performance is progressively negative. This implies that as organisational tenure increases teachers' job performances decline viz vasa, indicating a misfit between the person and the organisation. It was also revealed that job satisfaction was positively and directly related to job performance, while negative and significant linear relationship exist between organisational tenure and job performance (Borgogni, Russo, Petitta, \& Vecchione, 2010).

\section{The Nigerian Education System and Teachers Appointment}

Nigeria is a country that is made up of six geopolitical zones after gaining independence from the United Kingdom on $1^{\text {st }}$ of October 1960. At present, it has a federal system of government with the Federal Capital Territory in Abuja, 36 states and 774 local governments. The first secondary school was established in Nigeria in 1859 by the Church Missionary Society called CMS Grammar School in Barigal, Lagos. More schools were established before independence due to the willingness of people to acquire secondary education. Consequently, the number of secondary schools increased to 161 in 1955; 275 in 1956, 297 in 1957, 303 in 1958, 305 in 1959 and 311 in 1960 (Adesina, 1977 as cited in Ige, 2013). Nigeria's education system encompasses three different sectors: basic education (nine years), post-basic/senior secondary

\begin{tabular}{l} 
PROBLEMS \\
OF EDUCATION \\
IN THE 21 $1^{\text {st }}$ CENTURY \\
Vol. 77, No. 1, 2019 \\
\hline 255
\end{tabular} 
Yinusa A. FAREMI, Loyiso C. JITA. Assessment of science teachers' career satisfaction and school organisational climate in enhancing job performance in rural learning ecologies

OF EDU

IN THE $21^{\text {st }}$ CENTURY Vol. 77 , No. 1, 2019

256

tion (three years) and tertiary education (four to six years depending on the programme of study). The secondary education is made up of two components namely; the junior school ( 3 years) and senior school (3 years) in which the junior school is part of the basic education designed for nine years. In 2010, Nigeria reportedly had a total of 7,104 secondary schools with a population of 4,448,981 and a teacher to student ratio of about 32:1(Word Educational Services, 2017).

Ondo state was created out of the former Western Region called South West on 3rd February 1976 in which case Ekiti State was also created out of Ondo State on 1st October 1996. The first secondary school was established by the Christian missionaries in Ondo State, Nigeria dating back to 1919 . The number increased to 39 when Nigerian attained independence. The number of secondary schools increased to 251 as a result of free secondary education in 1979. In 1983 the number increased to 501, as a result of economic crunch and proliferation of secondary schools in the state, the state could no longer maintain the schools again, hence the schools were restructured and reduced from 501 to 463 in 1986 and 281 in 1996 (Ondo State Ministry of Education, 1985; 2006 as cited in Adeyemi, 2011). In order to know the total number of secondary schools in Ondo State in 2018, the Honourable Commissioner for Education in the state Mr. Femi Agagu commenced census of schools on 5 November 2018 in line with the federal government owned-school, which covers primary, secondary, technical and tertiary institution (Sowole, 2018).

The recruitment of teachers into schools is based on the policy of the Federal Republic of Nigeria as stated in the National Policy on Education in 2013. Teachers are recruited by the Federal Ministry of Education for the school owned by the federal government while the state ministry of education in collaboration with the Teaching Service Commission (TESCOM) recruit teachers into state owned schools. Teachers in the basic education sector are required to have a Nigerian Certificate of Education (NCE) awarded by Nigeria's teaching training colleges which is the minimum entry qualification into the teaching profession in Nigeria. Teachers at the senior secondary level must have been trained in the university faculties of education and awarded a Bachelor of Education or Bachelor's degree in another discipline with an additional certificate in education (Post Graduate Diploma in Education). In addition, they must possess evidence of membership of Teacher Registration Council of Nigeria (TRCN) through licensing, registration and enlisting of qualified teachers (Federal Republic of Nigeria, 2013; Ibenegbu, 2017). Admission into these programmes requires the senior secondary school certificate issued by the West African Examination Council (WAEC) and the National Examination Council (NECO). Other certificates are National Technical Certificate and the National Commercial Certificate issued by National Business and Technical Education Board (NABTEB) with adequate scores in the Unified Tertiary Matriculation Examination as specified by the Joint Admission and Matriculation Board (JAMB) and admission requirement of each university.

\section{Teacher Career Satisfaction in Enhancing Job Performance}

Teachers' career and their occupation are used interchangeably because a career is a synonym for job or occupation. Mahmood, Nudrat, Asdaque, Nawaz and Haider (2011) defined job satisfaction as an attitude, which results from balancing and summation of specific likes and dislikes experienced in connection with the job. The attitude may rest largely upon one's success or failure in the achievement of personal objectives and upon the perceived contribution of the job and employ organisation to these ends. It was also revealed during the interview carried out by Mahmood et al. (2011) that job dissatisfaction among teachers is as a result of excessive demands of the employers from the employees and lack of administrative support. 
Yinusa A. FAREMI, Loyiso C. JITA. Assessment of science teachers' career satisfaction and school organisational climate in enhancing job performance in rural learning ecologies

Narayan (2016) identified the key factors influencing mathematics teachers' effectiveness such as the teachers' content knowledge, teachers' collaboration and teacher career satisfaction. It was revealed that other environmental factors such as inadequate facilities and equipment, overcrowded classrooms, extra working hours and unhealthy associations with colleagues and administrators influenced teachers' effectiveness. Narayan (2016) states that teachers that are highly satisfied with their career would be willing to go the extra mile for their work unlike those who are unsatisfied. Highly satisfied teachers would be excited, cheerful and helpful to their students and colleagues.

Joo and Park (2010) as cited in Khalid and Khalid (2015), stated that career satisfaction of any employee can enhance by developing a supportive culture and taking into account the differences between employees. Akiri (2014) described satisfaction as the condition in which an individual found him/herself after a particular occurrence in the developed world and identified factors associated with teachers' career satisfaction such as helping students' positive association with colleagues and self-growth. While teachers' career dissatisfaction linked with low status, low pay, lack of professional autonomy and de-professionalization among others.

\section{School Organisational Climate in Enhancing Job Performance}

Organisational Climate is the process of quantifying the "culture" of an organisation; it precedes the notion of organisation culture. It is also a set of properties of the work environment as the employees of the organisation directly or indirectly perceived it as a major force in influencing employee behaviour (Huseynov, 2016).

Selamat, et al. (2013) found that organisational climate and secondary school teachers' job performance in Klang district demonstrated a moderate and positive linear relationship. The researchers also identified organisational climate as one of the factors that might influence teachers' job performance and the organisational climate dimensions can be measured based on principals' leadership behaviour and teachers' behaviour. Farooqi, Iqbal and Tahir (2015) defined the school climate as the reflection of norms, values, behaviour, beliefs, and attributes of the headteacher, teachers and students. Farooqi et al. (2015) agreed that school climate has a significant impact on learners' intellectual, emotional, social, and tangible development. For any teacher to be productive, he or she must possess some qualities of organisational commitment, that is, he or she must be committed to the degree to which they identify themselves with their organisations. The result of research carried out by Khalid and Khalid (2015) showed that organisational commitment significantly correlated with employee engagement and career satisfaction and the researcher identified three different types of organisational commitment that an employee can have:

1. An effective commitment that deals with the employee's emotional attachment to the organisation;

2. Continuance commitment: an employee stays with the organisation because he or she will incur costs if he or she leaves; and

3. Normative commitment: an employee takes it as a responsibility to remain with the organisation.

Balyer and Ozcan (2017) stated that organisational behaviour is determined by the organisational structure, their procedures, work definition, and role expectations. It is also considered an important and inferential aspect of satisfaction and retention as well as institutional effectiveness and success in education. A good organisational climate facility, good working relationships between the organisation's management and employees are associated with high degree of employees' satisfaction, performance, organisational commitment and a decrease in the intention to leave (Yousef, El-Maged, \& El-Houfey, 2014).

\begin{tabular}{l} 
PROBLEMS \\
OF EDUCATION \\
IN THE 21 $1^{\text {st }}$ CENTURY \\
Vol. 77, No. 1, 2019 \\
\hline 257
\end{tabular} 
Yinusa A. FAREMI, Loyiso C. JITA. Assessment of science teachers' career satisfaction and school organisational climate in enhancing job performance in rural learning ecologies

IN THE $21^{\text {st }}$ CENTURY Vol. 77 , No. 1,2019

258

Douglas, Muturi, Ochieng, and Douglas (2015) identified ten dimensions of organisational climate as challenges, idea time, dynamism, freedom, support, openness, conflicts, playfulness, debates and risk taking that could support improvement or undermine improvement of the lean six- sigma lifecycle. Selamat et al. (2013) also identified seven dimensions of organisational climate as thrust, hindrance, production emphasis, consideration, disengagement, esprit and intimacy which could enhance teachers' job performance. All these provide the conceptual basis for the six organisational climate dimensions used in this study such as:

1. Organisational support is the degrees to which science teachers believe that their school values their contributions and cares about their well-being. Organisational support plays a major role in rural learning ecologies in enhancing employees' creativity where they will be motivated to upgrade the organisation's performance and productivity. Organisational support was statistically significant in moderating how job stress and the six dimensions of nurses' job performance are related (Ibrahim, Isa, \& Shahbudin, 2016).

2. Teacher quality is about making an organisation perform for its stakeholders from improving the product, services, system and process, to making sure that the whole organisation is fit and effective. The quality of a teacher can also be determined by ensuring that the teacher accomplishes their work with vim, vigour and pleasure. The research conducted by Ramdhani, Ancok, Swasono and Suryanto (2012) indicated students and participating teachers perceiving that there are significant effects on a teacher quality training programme on the improvement of teachers' competence.

3. Openness means honesty and the willingness of the teacher to share knowledge, findings and views and provides a wider platform for collaborative knowledge development. Openness to experience plays an important role in explaining upward job change into managerial and related positions. Employees who are particularly open to experience seem to be promoted into managerial and professional positions (Nieß \& Zacher, 2015).

4. Supervisory style deals with how leaders in schools direct, implement plans and motivate teachers. This is a great concern in our secondary schools today and this may affect the stay of science teachers in rural schools. Johnson (2018) identified five different types of leadership styles. According to the Laisser-faire leadership style, the leaders are hand-off and they allow group members to make a decision. Autocratic leadership is the type of leadership wherein one person controls all the decisions, ideas and judgement and rarely accepts advice from members of the organisation. Participating leadership is the type of leadership that invites ideas from members of the organisation. Transactional leaders give rewards to staff after given assignments to do positively or negatively, while transformation leaders ensure team work exists in order to identify needed change and execute the change in tandem with committed members of the organisation. Tatlah and Iqbal (2012) found that there was a considerable connection between leadership styles and school effectiveness. It was also revealed that there was a significant difference between the leadership styles of head teachers/deputy head teachers in schools.

5. Conflict is a state of mind in which you find it impossible to make a decision. It can also be referred to as a disagreement and argument that can occur among science teachers in rural areas. Member conflict is a common problem in schools if it is not supervised and controlled in a practical way, it can prevent the school from reaching its goals and objectives and have a negative impact on the school climate (Shahmohammadi, 2014).

6. Teacher autonomy is the degree of freedom and discretion allowed to science teachers over their job. A high degree of autonomy engenders a sense of responsibility and improves the job satisfaction of teachers. Member autonomy related to laws and rules is set by the autonomous subjects themselves. The teacher autonomy debates have been influenced by wider global education trends and international comparisons (Wermke \& Salokangas, 2015). Teachers may learn more by taking care of the organisation that they belong to by receiving training related to their discipline when they are highly motivated to receive such training and motivated 
Yinusa A. FAREMI, Loyiso C. JITA. Assessment of science teachers' career satisfaction and school organisational climate in enhancing job performance in rural learning ecologies

teachers become physically involved in tasks. The characteristics of good work team members are honest and straightforward, share the load, reliable, fair, compliment others' skill, have good communication skills and a positive attitude (Riggio, 2013).

\section{Job Performance among Science teachers}

Job performance is the way a teacher behaves in the process of teaching and it is known to be related to their effectiveness (Selamat et al., 2013). Nag (2016) stated that employers differ in their personalities and these differences influence the way they react to the external and internal pressure that exists in any organisation. The researcher also identified 16 factors that lead to poor performance of employees at the workplace. These factors included personality, stress, heavy workloads, inadequate resources, poor leadership, lack of role clarity, lack of clarity about accountability, lack of transparency, a clash of values, gossip, poor selection of team members, outdated technology, harassment, perceived discrimination, poor performance management and depleting health conditions. On the other hand, Muda, Rafiki and Harahap (2014) identified job stress, motivation and communication as the factors associated with employee performance.

In research conducted by Sikul, Harun, Mohtar and Eranza (2015), it was revealed job satisfaction and job performance related significantly. It was found that job satisfaction plays an important role in motivating employees to a certain positive behaviour. Sikul et al. (2015) state that education alone could not be a determinant of job performance because of the different educational background of the teaching staff. It was also found that training and development are an important determinant for job performance among teachers of Kota Kinabalu Polytechnic (Sikul et al., 2015). Similarly, literature revealed that when employers are able to reward employees with a salary increase and bonuses, incentives such as restaurant gift cards and other inexpensive rewards boost employee morale (Shumate, 2017).

In a research conducted by Iacob and Cuza (2010) the relationship between conscientiousness and performance was Conscientiousness is the most stable in the study of consciousness factors and explains $22 \%$ of performance variance while extroversion explained $13 \%$. It was manifested that an organisation provides an orientation for newcomers to learn about the company through a continuous training programme, invests considerable time and money in training by providing comprehensive training that is not limited to skill training (Alsinawi, Piaw, \& Idris, 2015).

\section{Job performance of Science Teachers in Rural and Urban Learning Ecology}

Research conducted by Trentham and Schaer (1985), revealed that rural district teachers generally value rapport among teachers and the new teachers should be professional, and social with regard to the current teachers. It was also confirmed from the research that rural teachers seem more satisfied with the moral ethical self than urban teachers. Zhihao (2016) reported that the government of China has spent 5.3 billion Yuan (\$800million) subsidising for more than 1 million teachers in 600 disadvantaged geographical areas. The teachers in China received an average of 300 Yuan with some receiving more than 1,000 Yuan in comparison to their previous salaries. As a result of these benefits, teachers in rural areas are being appreciated more than ever. Increasing numbers of teachers in urban areas are now willing to work in rural areas as living benefits and teaching conditions improve.

In America, Smarick (2014) reported some factors that hinder improvement efforts in nine schools, neither a representative of rural nor urban schools in general such as distance to an urban centre or metro area, the geographical speed with low population density, and small community size. The results may be generalised to other rural schools as related to their ruralness. The involvement of parents in addressing these challenges met with some setbacks. Work schedules of the parents were the largest barrier to engagement and attendance of events such as

\author{
PROBLEMS \\ OF EDUCATION \\ IN THE $21^{\text {st }}$ CENTURY \\ Vol. 77, No. 1,2019 \\ 259
}


Yinusa A. FAREMI, Loyiso C. JITA. Assessment of science teachers' career satisfaction and school organisational climate in enhancing job performance in rural learning ecologies

PROBLEMS

OF EDUCATION

IN THE $21^{\text {st }}$ CENTURY Vol. 77, No. 1, 2019

260

parent-teacher conference, and lack of public and private transportation in rural areas as well as the distance between home, work and the school which prevents parents from becoming more involved in rural school development. These factors may significantly affect the performance of rural teachers in the area.

It was reported that rural schools in South Africa are the most disadvantaged mainly due to the lack of basic infrastructure, inexperienced educators and learners' motivation. These circumstances restrict rural schools from reaching their full potential (Kagiso Trust, 2016). In order to tackle these issues, the government, private and civil societies collaborated and provided a sustainable and measurable solution to improve the education system in rural ecologies. The collaboration yielded a good result in favour of Thabo Mofutsanyana District, which was the top performing district in the Free State province for three consecutive years (2013 to 2015).

Research showed that Zimbabwean schools have been hard hit by shortages of trained science teachers as a result of low enrolments in teacher training colleges, brain drain and economic challenges faced by the country (Chetsanga, 2000 as cited in Mhishi, Bhukuvhani, \& Sana, 2012). Teachers may view rural ecologies as offering fewer opportunities for professional growth and teachers in rural schools may even find it difficult to get their salaries on time. Literature revealed that there is a shortage of teachers, including science teachers, as a result of poor salaries, poor working conditions and job dissatisfaction (Subair \& Talabi, 2015). The results of the study carried out by Mahmood et al. (2011) indicated that there is no significant difference between urban and rural areas school teachers on job satisfaction. Generally, teachers in urban and rural areas were less satisfied with advancement, compensation, supervision, human-relation and working conditions.

In recent years, effects of teachers' career satisfaction and organisational climate on their job performance have become a topic of concerns for both researchers and educators. Although numerous researches have been conducted on the influence of job satisfaction or organisational climate on job performance without effort combining the two as independent variables to predict teachers' job performance in rural learning ecologies, are they will be saying that the combination of teachers' career satisfaction and organisational climate have no effect on their job performance, which begs for an answer. Past research has been constrained by a shortage of studies on the influence of science teachers' career satisfaction and school organisational climate on their job performance in rural learning ecologies. It was observed that request for transfer to urban schools still persists in Ondo State, despite the efforts made by the government in paying rural allowances to science teachers in order to encourage them to live and teach in the rural schools. Hence, it is crucial to determine the factor that could enhance job performance among science teachers in rural schools. However, this present study focusses on how teachers' career satisfaction and organisational climate dimensions such as organisational support, teacher quality, openness, supervisory style, member conflict, and teacher autonomy influence their job performance and willingness to live and teach in rural learning ecologies in Ondo State in order to fill the existing gap in the literature.

\section{Aim of Research}

The aim of this research was to:

- $\quad$ ascertain which of the science teachers' career satisfaction and school organisational climate is effective in predicting job performance;

- $\quad$ examine the relative contribution of science teachers' career satisfaction, school organisational climate to job performance; and

- $\quad$ find out which of the school organisational climate dimensions out of the six identified in this research is prevalent in enhancing teachers' job performance in rural learning ecologies. 
Yinusa A. FAREMI, Loyiso C. JITA. Assessment of science teachers' career satisfaction and school organisational climate in enhancing job performance in rural learning ecologies

One research question and four hypotheses were put forward to guide the current research:
What is the level of career satisfaction among science teachers in rural learning ecologies?

Hypothesis 1: The combination of teachers' career satisfaction and school organisational climate has no significant influence on their job performance

Hypothesis 2: Teachers' career satisfaction and school organisational climate have no significant effect on their job performance

Hypothesis 3: Teachers' career satisfaction, school organisational climate and their job performance are not significantly related

Hypothesis 4: The school organisational climate dimensions are not statistically significant in enhancing teachers' job performance

\section{Research Methodology}

\section{General Background}

This research employed correlational and survey designs of a quantitative type in which samples were chosen from the target population. Surveys is the process of gathering data at a particular point in time with the intention of describing the nature of existing condition or identifying standards against which existing conditions can be compared, or determining the relationships that exist between specific events, while correlation is the degree of relationship or association among variables (Cohen, Manion, \& Morrison, 2011). The two designs would enable the researchers to assess teachers' career satisfaction and school organisational climate in enhancing job performance in rural learning ecologies. In addition, it would enable the researchers to identify the organisational climate dimensions that could enhance job performance.

\section{Research Sample}

The sample for the research consisted of 250 science teachers, 25 secondary schools and two senatorial districts in Ondo State. The state is divided into three senatorial districts: Ondo Centre, Ondo North and Ondo South using stratified sampling technique. Ondo North and Ondo South were selected purposively due to high numbers of existing rural secondary schools in the areas. In Ondo South, 13 secondary schools were selected, while 12 secondary schools were from Ondo North to make a total of 25 secondary schools for the research. The schools were selected purposively due to the availability of the required science teachers per school for the research. Ten science teachers were required to participate in the research per school, where they are more than 10, a simple random technique was used to select the required 10 to make a total of 250 science teachers used for the research. Ary, Jacobs, Razavieh and Sorensen (2006) defined purposive sampling as the extent to which judgement can be relied on to arrive at a typical sample. It is also referred to as judgement sampling in which sample element judged to be typical, or representative are chosen from a population. Purposive sampling is appropriate for this research in order to ascertain the relative contributions of teachers' science career and school organisational climate to their job performance in rural learning ecologies. The researchers requested permission from the principals of the schools selected to conduct research and seek for the teachers' consent after the purpose of the research has been explained to them. Also, the researchers guarantee confidentiality and anonymity of all information provided. 
Yinusa A. FAREMI, Loyiso C. JITA. Assessment of science teachers' career satisfaction and school organisational climate in enhancing job performance in rural learning ecologies

$$
\begin{array}{r}
\text { PROBLEMS } \\
\text { OF EDUCATION } \\
\text { IN THE } 21^{\text {st }} \text { CENTURY } \\
\text { Vol. 77, No. 1, 2019 } \\
\hline 262
\end{array}
$$

\section{Instruments and Procedure}

Three research instruments were adapted and used for the research: The Minnesota satisfaction questionnaire renamed "Teachers' Career Satisfaction Questionnaire (TCSQ)", which was developed by Weiss, Danis, England and Lofquist (1967) as reported by Martins and Proenca (2012). It consists of a 20 -item scale with a Likert scale from very dissatisfied $=1$, dissatisfied $=2$, I am not sure $=3$, satisfied $=4$ and very satisfied $=5$, which was transformed into a 4-point Likert scale from very dissatisfied $=1$, dissatisfied $=2$, satisfied $=3$ and very satisfied $=4$. The second instrument titled the "School Organisational Climate Questionnaire (SOCQ)" with 18 items of a 4 - point Likert scale from almost never $=1$, infrequently $=2$, frequently $=3$ and very frequently $=4$ was developed by adapting the Organisational Climate Descriptive Questionnaire-Rutgers Elementary (OCDQ-RE) by Vos, Ellis, Van der Westhuizen and Mentz (2013). Three items related to each of the dimensions of organisational climate were selected (organisational support, teacher quality, openness, supervisory style, member conflict and teacher autonomy) from the adapted OCDQ-RE. The third instrument called the "Teacher Job Performance Questionnaire (TJPQ)" by Yusoff, Ali and Khan (2014) that contained 25 items from which 10 items were selected and redeveloped into a 4-point Likert scale from strongly disagree $=1$, disagree $=2$, agree $=3$ and strongly agree $=4$. The validity of the instruments was determined using face and content validity by a Test and Measurement expert in which some items were modified. The new version of the questionnaires was administered to 20 selected science teachers in the rural schools that share a boundary with Ondo State that was not included in the samples for the study. Data collected were subjected to Cronbach's Alpha with the following reliability coefficient values: Teachers' Career Satisfaction Questionnaire $(\mathrm{TCSQ})=.85$, School Organisational Climate Questionnaire $(\mathrm{SOCQ})=.80$ and Teacher Job Performance Questionnaire $(\mathrm{TJPQ})=.71$. The questionnaires were administered with the help of the schoolteachers and trained research assistants under the guidance of one of the researchers. The questionnaires were given to teachers to complete during working hours and collected back after completion.

\section{Data Analysis}

Data collected were analysed using descriptive and inferential statistics. The research question was answered using frequency count and percentage, hypothesis 1, 2, 3 and 4 were tested using inferential statistics such as correlation matrix and regression analysis. The correlation matrix was used to find the relationship that exists among the independent variables such as science teachers career satisfaction, school organisational climate and the dependent variable (job performance) while the regression analysis was used to find the significant effect of the independent variables on the dependent variable and the contribution of the independent variables to the dependent variable.

\section{Research Results}

Research question one: What is the level of career satisfaction among science teachers in rural learning ecologies? 
Yinusa A. FAREMI, Loyiso C. JITA. Assessment of science teachers' career satisfaction and school organisational climate in enhancing job performance in rural learning ecologies

Table 1. Level of science teachers' career satisfaction.

\begin{tabular}{lll}
\hline Level & Frequency & Percentage (\%) \\
\hline Satisfied & 163 & 65.2 \\
\hline Dissatisfied & 87 & 34.8 \\
\hline Total & 250 & 100 \\
\hline
\end{tabular}

As can be seen in table 1, the findings revealed that $163(65.2 \%)$ demonstrated satisfaction with their teaching career in science subjects while 87 (34.8\%) teachers demonstrated dissatisfaction with their teaching career in science subjects. This means that $65.2 \%$ of the science teachers in rural learning ecologies are satisfied with their job while the remaining $34.8 \%$ of the science teachers were not satisfied with their job.

Hypothesis 1: The combination of teachers' career satisfaction and school organisational climate has no significant influence on their job performance.

Table 2. Regression analysis of the combined independent variables.

\begin{tabular}{|c|c|c|c|c|c|c|c|c|}
\hline$R^{2}$ & SS & MS & $F$ & & $p$ & $R$ & $R^{2}$ & Adjusted \\
\hline Regression & 3708.505 & 2 & 1854.252 & 12.980 & .0001 & .308 & .095 & .088 \\
\hline Residual 3528 & $2.631 \quad 247$ & 142.845 & & & & & & \\
\hline Total & 38991.136 & 249 & & & & & & \\
\hline
\end{tabular}

Predictor variables: TCS=teachers' career satisfaction, $\mathrm{OC}=$ organisational climate,

Dependent variable: job performance

As seen in table 2, the school organisational climate and teachers' career satisfaction combined significantly to influence their job performances $\left(F_{(2,247)}=12.980, p<.05\right)$. The R-value of .308 showed the coefficient of multiple correlations between the independent variables and the dependent variable. The $\mathrm{R}$ square value was .095 , this means that the predictor variables accounted for $9.5 \%$ of the variance in the dependent variable which is low. The adjusted R square value was .088, this means that the predictor variables accounted for $8.8 \%$ of the variance in the dependent variable in terms of the population rather than the sample. The remaining variance could be attributed to other variables not included in this model.

Hypothesis 2: teachers' career satisfaction and school organisational climate have no significant effect on their job performance.

Table 3. Test of effect of the independent variables on the dependent variable.

\begin{tabular}{llcccc}
\hline Model & $\boldsymbol{B}$ & Std. Error & Beta & $\boldsymbol{t}$ & $\boldsymbol{p}$ \\
\hline Constant & 45.957 & 6.578 & & 6.987 & .001 \\
Teacher career satisfaction & .389 & .091 & .258 & 4.261 & .001 \\
School organisational climate & -.495 & .172 & -.174 & -1.879 & .543 \\
\hline
\end{tabular}

As indicated in table 3, Beta $=.258, \mathrm{t}=4.261, p<.05$ for teachers' career satisfaction. This means that the teacher career satisfaction had the strongest positive effect on their job performances, and it makes the most significant relative contribution to the prediction of job performances. While Beta $=-.174, t=-1.879, p<.05)$ for school organisational climate, this means that it has a very weak negative effect and made no significant relative contribution to the prediction of teacher job performances. 
Yinusa A. FAREMI, Loyiso C. JITA. Assessment of science teachers' career satisfaction and school organisational climate in enhancing job performance in rural learning ecologies

OF EDUCAT IN THE $21^{\text {st }}$ CENTURY Vol. 77 , No. 1, 2019

264

Hypothesis three: Teacher career satisfaction, school organisational climate and their job performance are not significantly related.

Table 4. Correlation among teacher career satisfaction, school organisational climate and job performance.

\begin{tabular}{lcccc}
\hline & TCS & OC & JP & \\
\hline & & & & \\
Teachers' career satisfaction (TCS) & 1 & & & \\
School organisational climate (SOC) & .020 & 1 & & \\
Teachers' job performance (TJP) & & .254 & -.169 & 1 \\
\hline
\end{tabular}

Level of Significance was taken at .01

As indicated in table 4, teachers' career satisfaction $(r=.254, p<.05)$ has a significant positive relationship with their job performances while school organisational climate $(r=-.169$, $p<.05$ ) has a significant negative relationship with teachers' job performances. This means that teachers' career satisfaction has a good relative influence on job performance when compared with school organisational climate.

Hypothesis 4: The school organisational climate dimensions are not statistically significant in enhancing teachers' job performance.

Table 5. Correlation matrix analysis of school organisational climate dimensions and job performance.

\begin{tabular}{|c|c|c|c|c|c|c|c|}
\hline Organisational Dimensions & OS & $\mathrm{TQ}$ & OP & SS & MC & MA & JP \\
\hline Organisational support (OS) & 1 & & & & & & \\
\hline Teacher quality (TQ) & $.344^{* *}$ & 1 & & & & & \\
\hline Openness (OP) & $.591^{* *}$ & $.311^{* *}$ & 1 & & & & \\
\hline Supervisory style (SS) & $.464^{* *}$ & $.400^{* *}$ & $.396^{* *}$ & 1 & & & \\
\hline Member conflict (MC) & $.236^{* *}$ & $.280^{* *}$ & $.302^{* *}$ & $.332^{* *}$ & 1 & & \\
\hline Teacher autonomy (MA) & $.429^{\prime \prime}$ & $.269^{* *}$ & $.406^{* *}$ & $.410^{* *}$ & $.277^{* *}$ & 1 & \\
\hline Job performance (JP) & $.124^{*}$ & .104 & $.226^{* *}$ & $.201^{* *}$ & $.150^{*}$ & $.233^{* *}$ & 1 \\
\hline
\end{tabular}

As indicated in table 5, organisational support $(r=.124, p<.05)$, openness $(r=.226, p<.05)$, supervisory style $(r=.201, p<.05)$, member conflict $(r=.150, p<.05)$ and teacher autonomy $(r=.233, p<.05)$ have a significant positive relationship in enhancing teachers' job performance. While teacher quality $(r=104, p>.05)$ had no significant relationship with job performance, this means that five out of the six organisational climate dimensions can enhance teachers' job performance at .05 level of significance.

\section{Discussion}

The results of the statistical analysis in the research question showed that $65.2 \%$ of science teachers were satisfied. This implies that the more satisfied the present science teachers in rural learning ecologies are the more productive they are. This might have a positive impact on their job performance and wiliness to live and teach in rural schools. This finding also confirms the finding of Narayan (2016) who reported that if teachers are highly satisfied with their career, they would be willing to go the extra mile to do their teaching tasks unlike those who are unsatisfied. In addition, Naz (2017) reveals that low job satisfaction adversely affects the productivity level of even highly qualified and skilled teachers. Furthermore, Shumate (2017) 
Yinusa A. FAREMI, Loyiso C. JITA. Assessment of science teachers' career satisfaction and school organisational climate in enhancing job performance in rural learning ecologies

affirms that until employers are able to reward employees with salary increments and bonuses, other minor rewards may be ineffective of boosting their morale. The statistical analysis also showed that 34.8 percent of the science teachers were not satisfied with their career. Mahmood et al. (2011) confirmed that those who are dissatisfied with their jobs are as a result of excessive demands and lack of administrative support.

The result of hypothesis one seeks to establish the fact that the duo of science career satisfaction and school organisational climate significantly combine to influence job performance in rural schools where the predictors account for $9.5 \%$ of the variance in the dependent variable which is low. Further verification of the result of hypothesis two shows that teachers' career satisfaction out of the two predictor variables identified in this study has the most predictive power and relative positive contribution to their job performances. This might be as a result of the satisfaction received by the present science teachers in rural schools. The findings showed that the school organisational climate was not an effective predictor and has a negative contribution to job performances. This might be as a result of unhealthy organisational dimensions within the organisation which is supposed to be an array of strategies in enhancing teachers' job performance. The negative result implies that the more problematic an organisational climate is, the less productive teachers are. The current study supports the findings of Borgogni, et al. (2010) that job performance is positively predicted by job satisfaction and the relationship that exists between organisational tenure and job performance is progressively negative.

The result of hypothesis three reveals a significant and positive relationship between science teachers' career satisfaction and job performance. This shows that career satisfaction has a positive influence on teachers' job performances. The findings are similar to those found by Sikul et al. (2015) that there is a significant relationship between job satisfaction and job performance among teachers of Kota Kinabalu Polytechnic. Furthermore, the study highlights a significant and negative influence of school organisational climate on job performance. This implies that the school organisational climate has a negative impact on teachers' job performances. This finding contradicts the finding of Selamat, et al. (2013) who found that organisational climate and secondary school teachers' job performance in Klang district demonstrated a moderate and positive linear relationship.

The result of hypothesis four reveals that organisational support, openness, supervisory style, member conflict and teacher autonomy are prevalent in enhancing teachers' job performance and willingness of science teachers to live and teach in rural learning ecologies in Ondo State, while teacher quality is not prevalent in enhancing teachers' job performance. Monk (2007) as cited in Barley (2008) found that rural schools face difficulty in recruiting and retaining new teachers, not only because of high teacher's requirement, but also the teaching conditions that are unique to rural schools (unfriendly school organisational climate). Such rural conditions often discourage teachers from accepting a rural teaching position or cause them to leave the rural settings after teaching for a short period of time. This consequently might lead to a shortage of science teachers in rural learning ecologies. The findings of this study are also in accordance with the position of Narayan (2016) who found that an unhealthy relationship with colleagues and administrators could influence teachers' effectiveness negatively. Nieß et al. (2015) support the fact that openness is one of the factors that must be encouraged among teachers in order to be satisfied with their jobs for effective performance. In addition, the principal leadership style that lacks transparency and trust creates underperformance of teachers and this might affect the academic achievement of the students in science subject (Nag, 2016; Shumate, 2017; Selamat \& Samsu, 2013).

\author{
PROBLEMS \\ OF EDUCATION \\ IN THE $21^{\text {st }}$ CENTURY \\ Vol. 77, No. 1, 2019 \\ 265
}


Yinusa A. FAREMI, Loyiso C. JITA. Assessment of science teachers' career satisfaction and school organisational climate in enhancing job performance in rural learning ecologies

\section{PROBLEMS \\ OF EDUCATION \\ IN THE $21^{\text {st }}$ CENTURY \\ Vol. 77 , No. 1,2019 \\ 266 \\ Conclusions and Implications}

Based on the results of this research, it is evident that $65.2 \%$ of science teachers in rural learning ecologies are satisfied with their career. Teachers' career satisfaction has a significant positive relative influence on job performance and makes the most significant relative contribution to teachers' job performance in rural learning ecologies. The school organisational climate has a significant negative relationship with job performance and is not an effective predictor of teachers' job performance in rural learning ecologies. This implies that the more organisational climate becomes problematic, the lower the job performance of science teachers in rural schools. However, only teacher quality of the six school organisational climate dimensions could not enhance teachers' job performance. From the findings, several implications can be inferred. If employers of science teachers and principals of the schools are committed to creating a healthy school organisational climate and demonstrate good leadership behaviour, there is going to be an improvement in the job performance of science teachers. Moreover, conflicts should be resolved in a practical way either by constituting a conflict management committee, if it happens by the school head. This is essential in order for the conflicts not to have a negative impact on the school climate and hinder the goals and objectives of the school. Teacher autonomy should also be granted, leader behaviour towards teachers must be improved upon and support must be given to science teachers in order to increase their productivity. Finally, the study has revealed the need for the heads/principals and other stakeholders to take into account the variables considered in enhancing job performance in this study while addressing the issues of shortage and unwillingness of science teachers to teaching in rural schools.

\section{References}

Adeyemi, T. O. (2011). The supply of science teachers to secondary schools in Ondo State, Nigeria: A critical analysis. Asian Journal of Information Management, 5(1), 12-24. doi: 10.3923/ ajim.2011.12.24

Al-Sinawi, S., Piaw, C. Y., \& Idris, A. (2015). Factors influencing the employees' service performance in the ministry of education in Sultanate of Oman. Procedia - Social and Behavioral Sciences, 197, 23 - 30. DOI: 10.1016/j.sbspro. 2015.07.043.

Akiri, A. A. (2014). Teachers' career satisfaction and students' academic performance in Delta public secondary schools. Journal of Educational and Social Research, 4(1), 267-272. Retrieved from https://pdfs.semanticscholar.org/5e5c/2ef65f 2fa984aa2bc2a53565802e 10b58444.pdf

Ary, D., Jacobs, L. C., Razavieh, A., \& Sorensen, C. (2006). Introduction to research in education ( $7^{\text {th }}$ ed.). United State: Thomson Wadsworth.

Barley, Z. A. (2008). Preparing teachers to teach in rural schools. Retrieved from ies.ed.gov/ncee/edlabs/ central/pdf/REL 200804 sum.Pdf

Balyer, A., \& Ozcan, K. (2017). The organizational climate at primary schools and its influences on teachers' job satisfaction. Kastamon Education Journal, 25(5), 1737-1752. Retrieved from http:// dergipark.gov.tr/download/article-file/ 348789

Borgogni, L., Russo, S. D., Petitta, L., \& Vecchione, M. (2010). Predicting job satisfaction and job performance in a privatized organization. International Public Management Journal, 13(3), 275 296. doi: 10.1080/10967494. 2010. 504114.

Castro, M., \& Martins, N. (2010). The relationship between organisational climate and employee satisfaction in a South African information and technology organisation. SA Journal of Industrial Psychology/SA Tydskrif vir Bedryfsielkunde, 36(1). Doi: 10.4102/sajip.v36i1.800

Cohen, L., Manion, L., \& Morrison, K. (2011). Research methods in education $\left(7^{\text {th }}\right.$ ed.). New York: Routledge Taylor and Francis Group. 
Yinusa A. FAREMI, Loyiso C. JITA. Assessment of science teachers' career satisfaction and school organisational climate in enhancing job performance in rural learning ecologies

Douglas, J., Muturi, D., Ochieng, J., \& Douglas, A. (2015). Organizational climate and readiness for change to learn six sigmas. Retrieved from https://www.researchgate.net/ publication/275954980.

Farooqi, M.T.K., Iqbal, A., \& Tahir, M. S. (2015). Relationship of organizational climate with teachers' job performance. The Journal of Educational Research, 18 (1), 56. Retrieved fromhttps://www. questia.com/library/journal/1P3-4080057281/relationship-of-organizational-climate-withteachers

Federal Republic of Nigeria (2013). National policy on education $\left(6^{\text {th }}\right.$ ed.). Lagos: NERDC.

Hlalele, D. (2011). Creating sustainable rural learning ecologies. Retrieved from http://www. ufs.ac.za/ docs/librariesprovider41/new-frontiers.

Huseynov, K. (2016). What is Organisation Climate and why it is important? Retrieved from https:// www.linkedin.com/pulse/what-organisation-climate-why-important-huseynov-phd-assoc-cipd.

Ibenegbu, G. (2017). Functions of teachers' registration council of Nigeria (TRCN). Retrieved from https://www.legit.ng/1120947-functions-teachers-registration-council-nigeria.html.

Ibrahim, H. I., Isa, A., \& Shahbudin, A. S. M. (2016). Organizational support and creativity: the role of developmental experiences as a moderator. Procedia Economics and Finance, 35, 509-514. doi. org/10.1016/S2212-5671 (16)00063-0.

Iacob, G. A., \& Cuza, A. I. (2010). Factors that determine job performance. Studies and Scientific Researches Economic Edition, 15, 365-372. doi: 10.29358/sceco.v0i15.141.

Ige, A. M. (2013). Provision of secondary education in Nigeria: Challenges and way forward. Journal of African Studies and Development 5(1), 1-9. doi: 10.5897/JASD11.058.

Johnson, R. (2018). 5 different types of leadership styles. Retrieved from http://smallbusiness.chron. com/5-different-types-leadership-styles-17584. html.

Kagiso Trust, (2016, October). Building on lessons learn for the development of rural education. Retrieved on 20 June 2018 from http://www.kagiso.co.za/lessons-for-development-of-rural-education/ruraleducation.

Khalid, A., \& Khalid, S. (2015). Relationship between organizational commitments, employee engagement and career satisfaction a case of University of Gujrat, Pakistan. Journal of South Asian Studies, 3(3), 323-330. Retrieved from http://escijournals.net/index.php/ JSAS/article/ view/732\#.W P7bekYDZY.

Mahmood, A., Nudrat, S., Asdaque, M. M., Nawaz. A., \& Haider. N. (2011). Job satisfaction of secondary school teachers: A comparative analysis of gender, urban and rural schools. Asian Social Science, 7 (8), 203-208. doi:10.5539/ass.v7n8p203.

Martins, H., \& Proenca, T. (2012, October). Minnesota satisfaction questionnaire-psychometric properties and validation in a population of Portuguese hospital workers. FEP working Paper, 1-24. Retrieved from www.fep.up.pt/investigacao/ workingpapers/wp471.pdf.

Mertler, C. A. (2016). Should I stay or should I go? Understanding teacher motivation, job satisfaction, and perceptions of retention among Arizona teachers. International Research in Higher Education, 1(2), 34-45. doi.org/ 10.5430/irhe.v1n2p34.

Mhishi, M., Bhukuvhani, C. E., \& Sana, A. F. (2012, January). Science teacher training program in rural schools. An ODL lesson from Zimbabwe. The International Review of Research in Open and Distance Learning, 13(1), 72-86. Retrieved from http:/www.irrodl.org/index.php/ irrodl/article/ view/1058/2082.

Muda, I., Rafiki, A., \& Harahap, M. R. (2014). Factors influencing employees' performance: a study on the Islamic banks in Indonesia. International Journal of Business and Social Science, 5(2), 73-80. Retrieved from http://ijbssnet.com/journals/Vol_5_No_2_February_2014/9.pdf.

Nag, A. (2016). 16 factors that lead to poor performance at the workplace, Commlab India. Retrieved 19 June 2018 from https://blog.commlabindia.com/elearning-design/negative -performance-factors.

Narayan, N. A. (2016). Factors influencing teacher career satisfaction, teacher collaboration and everyday challenges: an exploratory factor analysis. Malaysian Online Journal of Educational Sciences, 4(3), 24-38. Retrieved from https://files.eric.ed.gov/ fulltext/ EJ1106454.pdf.

Naz, S. (2017). Factors affecting teachers job satisfaction. Market Forces, 11(2), 44-59. Retrieved fromhttp://pafkiet.edu.pk/marketforces/index.php/ marketforces/article/view/343.

PROBLEMS
OF EDUCATION
IN THE 21 $1^{\text {st }}$ CENTURY
Vol. 77, No. 1, 2019 
Yinusa A. FAREMI, Loyiso C. JITA. Assessment of science teachers' career satisfaction and school organisational climate in enhancing job performance in rural learning ecologies

\section{PROBLEMS \\ OF EDUCATION \\ IN THE $21^{\text {st }}$ CENTURY} Vol. 77, No. 1, 2019

268

Nieß, C., \& Zacher, H. (2015). Openness to experience as a predictor and outcome of upward job changes into managerial and professional positions. Open Access Journal, 10 (6). Retrieved from http:// www.ncbi.nlm.nih.gov/pmc/ articles/PMC 4482250/.

Ramdhani, N., Ancok, D., Swasono, Y., \& Suryanto, P. (2012). Teacher quality improvement program: Empowering teachers in increasing a quality of Indonesian's education. Procedia - Social and Behavioral Sciences 69, 1836-1841. doi: 10.1016/j.sbspro.2012.12.134

Riggio, R. E. (2013). Characteristics of good work team members. Psychology Today. Retrieved from www.psychologytoday.com/us/blog/cutting-edge-leadership/201301/characteristics-good-workteam-members.

Selamat, N., Samsu, N. Z., \& Kamalu, N. S. M. (2013). The impact of organizational climate on teachers' job performance. Educational Research Journal, 2(1), 71-82.

Shumate, B. (2017). Factors that influence employee performance. Retrieved on 19 June 2018 from https://bizfluent.com/list-6878597-factors-influence-employee-performance.html.

Shahmohammadi, N. (2014). Conflict management among secondary school students. Procedia - Social and Behavioral Sciences, 159, 630-635. doi.org/10.1016/j.sbspro.2014.12.438

Sikul, R., Harun, A., Mohtar, T. M., \& Eranza, D.R.D. (2015). Factors influencing job performance: A case study amongst teaching staff in Kota Kinabalu Polytechnic. Malaysian Journal of Business and Economics 2(2), 41-58. Retrieved from https://jurcon.ums.edu.my/ojums/index.php/mjbe/ article/view/598.

Smarick, A. (2014). The challenges facing struggling rural schools. Education Next. Retrieved on 18 June 2018 from www.educationnext.org/challenges-facing-struggling-rural-schools/.

Sowole, J. (2018, November). Ondo state census of schools. This Day. Retrieved fromhttps://www. thisdaylive.com/index.php/2018/02/16/ondo-starts-census-ofschools/

Subair, S. T., \& Talabi, R. B. (2015). Teacher shortage in Nigeria schools: Cause, effects, and administrators coping strategies. Asia Pacific Journal of Education, Art and Sciences 2(4), 31-37. Retrieved from http://apjeas.apjmr.com/wp-content/uploads/2015/10/APJEAS-2015-2.4.1.05.pdf.

Tatlah, I. A., \& Iqbal, M. Z. (2012). Leadership styles and school effectiveness: Empirical evidence from secondary level. Procedia - Social and Behavioral Sciences 69, 790-797. https://doi.org/10.1016/j. sbspro.2012.11.474.

Trentham, L. L., \& Schaer, B. B. (1985). Rural and urban teachers: Differences in attitudes and selfconcepts. Research in Rural Education, 3 (1), 3-5. https://eric.ed.gov/?id=EJ334937

Vos, D., Ellis, S. M., Van der Westhuizen, P.C., \& Mentz, P. J. (2013). Applicability of the organisational climate description questionnaire-Rutgers elementary: A South Africa case study. South African Journal of Education, 33(3), 1-18. doi.org/10.15700/201503070759

Wermke, W., \& Salokangas, M. (2015). Autonomy in education: Theoretical and empirical approaches to a contested concept. Nordic Journal of Studies in Educational Policy, 1-6. Retrieved from www. tandfonline.com/doi/pdf/ 10.3402/nstep.v1.28841.

Yousef, H.R., El-Maged, N.SH.A., \& El-Houfey, A.A. (2014). Organizational climate correlates nurses' intention to leave work. Public Policy and Administration Research,4 (4), 14-21.Retrieved from https://www.researchgate.net/publication/276025626_Organizational__Climate_Correlates_ Nurses' Intention to Leave.

Yusoff, R.B.M., Ali, A.M., \& Khan, A. (2014). Assessing reliability and validity of job performance scale among university teachers. Journal of Basic and Applied Scientific Research, 4(1), 35-41. Retrieved from https://www.textroad.com/pdf/JBASR/ J.\% 20Basic.\% 20Appl. \% 20 Sci.\% 20 Res.,\%204(1)35-41,\%202014.pdf.

Zhihao, Z. (2016). More teachers willing to work in rural schools as conditions improve. Retrieved 18 June from http://www.chinadaily.com.cn/ china/2016-. 
Yinusa A. FAREMI, Loyiso C. JITA. Assessment of science teachers' career satisfaction and school organisational climate in enhancing job performance in rural learning ecologies

Received: October 13, 2018

Accepted: March 10, 2019

PROBLEMS

OF EDUCATION

IN THE $21^{\text {st }}$ CENTURY

Vol. 77, No. 1, 2019

269

Yinusa A. Faremi Ph.D., Postdoctoral Research Fellow, Faculty of Education, University of the Free State, Bloemfontein, South Africa.

E-mail: akintoyeyinusa@gmail.com

Loyiso C. Jita Ph.D., Professor, Dean and SANRAL Chair in Science and Mathematics Education, Faculty of Education, University

of the Free State, Bloemfontein, South Africa

E-mail: jitaLC@ufs.ac.za 